Egyptian Veterinary Medical Society of Parasitology Journal

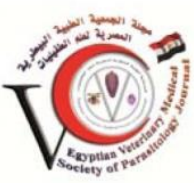

\title{
Prevalence of Trichostrongyle eggs infecting sheep and goats in Dakahlia Governorate, Egypt
}

\section{Elsedawy, M. Rana, Al-Araby, M., Abbas, I. and Abu- Elwafa, S. A. Department of Parasitology, Faculty of Veterinary Medicine, Mansoura University, Egypt.}

\begin{abstract}
:
Gastrointestinal nematodes, principally those of family trichostrongylidae are considered one of the most important parasitic diseases allover the world, that causing significant drop of small ruminants productivity. This study was performed from October 2017 to September 2018 in 5 centers geographically located in and around Dakahlia governorate, Egypt. Faecal samples were examined using modified wisconsin technique. Examination of 455 faecal samples from sheep and goats revealed an overall incidence of $28.5 \%$ (130 out of 455). Sheep is found more affected by trichostrongyles (33.23\%) than goats $(14.78 \%)$. The highest infection rate of trichostrongyle eggs was recorded in El Mahella Elkubra (92.5\% and $27.8 \%$ in sheep and goats, respectively) while, the lowest infection rate was detected in Biyala city $(10 \%$ and $0 \%$ in sheep and goats, respectively). Females are found more infected than males and young ages are found more infected than older ones in both examined sheep and goats. Regarding the seasonal fluctuation; the infection rate in sheep reached at its maximum level during Winter (57.1\%) while in goats was during Summer (18.7\%).

Key Words: Trichostrongyles, Prevalence, Sheep and goats, Dakahlia governorate, Egypt.
\end{abstract}

\section{INTRODUCTION}

Sheep and goats represent a major source for protein and wool as well as manure especially in rural economy for non-agricultural low class of people (Nawathe et al., 1985). Most health obstacles in small ruminants are parasitic infection (Gadahi et al., 2009) which can cause death (Pawel et al., 2004; Abouzeid et al., 2010). Multiple investigations were described the parasitic nematode species (Garcia et al., 1993; Rehbein et al., 1996; 
Fakae et al., 1990) to decrease feed intake followed by little work capacity that lead to low productivity (Pedreira et al., 2006; Odoi et al., 2007; Chaudhary et al., 2007). In addition, anthelmintic resistance has extended overall major parasite species (Veale, 2002) particularly Trichostrongyloidae (Coop et al., 1977; Steel et al., 1982; Waller, 1997; Pawel et al., 2004). Family Trichostrongylidae is one of the worldwide serious gastrointestinal parasites infecting sheep and goats. They include; Haemonchus contortus, Ostertagia leptospicularis, Cooperia curticei, Teladorsagia circumcincta, Trichostrongylus axei and Trichostrongylus colubriformis. They are lead to severe economic losses such as declined fleece production, weight loss and considerable morbidity. Teladorsagia spp. and Ostertagia spp. are ordered secondly after the more pathogenic blood sucking Haemonchus contortus in their pathogencity levels (Zarlenga et al., 2016). Considering significance of both sheep and goats in our community and the substantial losses that are caused by GIT nematodes, the current study was designed to assess infection rate of trichostrongyle eggs influencing sheep and goats in 5 centers located in and around Dakahlia governorate; bearing in the mind the associated determinants like age and sex as well as seasonal fluctuations.

\section{MATERIAL AND METHODS}

\section{Study area, animals and sampling:}

In this study, 340 sheep and 115 goat faecal samples of different ages and sex are collected from animals reared in the major private farms, little non composed ranches as well as animals owned by agriculturists from Dakahlia governorate and surrounding centers. The period of study is extended from October 2017 till September 2018. Sheep samples were represented as 160 samples from Talkha, 40 samples from Dekernes, 83 samples from Nabrouh, 27 samples from El Mahella Elkubra and 30 samples from Biyala.

Goat samples were represented as 68 samples from Talkha, 7 samples from Dekerense, 12 samples from Nabrouh, 18 samples from El Mahella -Elkubra and 10 samples from Biayla.

\section{Collection of faecal samples:}

A total of 455 fresh faecal samples were collected from rectum of the examined sheep and goats into plastic bags and labelled with site, age, sex and date. They were kept cool and eventually transferred to Parasitology Lab., Fac. of Vet. Med., Mans. Uni. for faecal analysis.

\section{Coprocological examination:}

Fresh faecal samples were examined for trichostrongyle eggs using modified wisconsin technique according to Cox and Todd, (1962). The used saturated sugar solution as a flotation fluid was titrated up 
to reaching the specific gravity of 1.26 using hydrometer (high S.T. $=75 \mathrm{mN} / \mathrm{m}$, Germany). The samples were inspected under microscope using $\mathrm{x} 4$ and $\mathrm{x} 10$ objective lenses.

\section{RESULTS}

I- Incidence of trichostrongyle eggs revealed from sheep and goats faecal samples in study area:

Morphologically, except for the large characteristic Nematodirus spp. eggs, trichostrongyle eggs are small, ellipsoid in shape, colourless with thin wall and containing undifferentiated contents (Soulsby, 1982). Figure, 1.

Microscopic detection of trichostrongyle eggs in faecal samples from sheep and goats in 5 districts (3 in Dakahlia governorate and 2 districts at its borders) revealed an overall incidence of $33.23 \%$ $(113 / 340)$ in sheep and $14.78 \%(17 / 115)$ in goats. In sheep; the highest infection rate was recorded in faecal samples from El Mahella -Elkubra (92.5\%, 25 out of 27) followed by Talkha $(34.3 \%, 55$ out of 160), Dekernes (30, 12 out of 40) then Nabarouh (21.6\%, 18 out of 83$)$ and finally Biyala (10\%, 3 out of 30$)$. In goats; the more incidences were found in faecal samples from El Mahella -Elkubra $(27.8 \%, 5$ out of 18) followed by Nabrouh $(16.6 \%, 2$ out of 12), Dekernes (14.2\%, 1 out of 7) and ultimately Talkha $(13.2 \%, 9$ out of 68$)$ whereas no infection in goats was noted in Biyala city, (Table, 1).

\section{II- Incidence of trichostrongyle eggs revealed from sheep and goats faecal samples in relation to ages:}

Young aged animals less than 1 year are found highly infected with trichostrongyle eggs $(78.35 \%$ for sheep and $20.27 \%$ for goats) than those more than 1 year $(15.22 \%$ for sheep and $4.87 \%$ for goats), Table, 2.

III- Incidence of trichostrongyle eggs in sheep and goat faecal samples regarding to animal sex:

Females of both examined animal species are found highly infected with trichostrongyle eggs (36\% in sheep and $20.27 \%$ in goats) more than males $(8.57 \%$ in sheep and $4.87 \%$ in goats), Table, 3 .

\section{IV-Seasonal incidence of trichostrongyle} eggs in sheep and goat faecal samples:

In sheep faecal samples, the rate of infection with trichostrongyle species is found to increase gradually during Autumn (33.9\%, 19 out of 56) reaching its maximum level during Winter $(57.1 \%, 84$ out of 147) then declined slightly during Spring (33.3\%, 10 out of 30) and completely disappear in Summer season $(0 \%, 0$ out of 107).

In goats, the infection with trichostrongyles is recorded only during Summer $(18.7 \%, 15$ out of 80$)$ and Winter (13.3\%, 2 out of 15), 
while was absent during Autumn and Spring seasons (0\%), Table, 4.

\section{DISCUSSION}

In the present study, the faecal examination showed a high incidence of trichostrongyle eggs (33.2\%) in sheep in Dakahlia governorate and two centers at its borders. Lower incidences were reported from other governorates in Nile Delta. For instance, Khalafalla et al., (2011) recorded 10.4\% incidence at El Mahella -Elkubra, Gharbiya governorate whereas, $19.21 \%$ was found in Kafr- Elsheikh governorate by Sultan et al., (2016). The incidence of infection was $8.91 \%$ in Aswan by Hamad, (2018). Moreover, high incidences were found in various regions as $26.15 \%$ infection rate was in the following governorates (Ismailia, Port-Said and Damietta) by Assasa, (2018) while 27.5\% was in Sinai (Abouzeid et al., 2010) and also 31.4\% from Sohag (Al-Aboody and Omar, 2016). Meanwhile, higher incidences of 44.57 and $75.77 \%$ were found in both Menofia and Beheira governorates, respectively (El-khtam, 2011; Menshawy, 2011). In addition, El-Alfy (2017) reported a much higher incidence of $51.63 \%$ in Dakahlia, the same study governorate. Globally, high incidences were recorded within various regions from the same country. Incidence of trichostrongyles in this study (30-40\%) is found within the range that recorded in Iran by Nabavi et al.
(2011). Furthermore, a report of Nwosu et al. (2007) in Nigeria recorded a lower incidence $(22.5 \%)$, while a higher incidence of $71 \%$ was recorded from the same country by Gana et al. (2015). The incidence was ranging from $47.8 \%$ to 97.03\% in Ethiopia (Abede and Esayas, 2001; Thomas et al., 2007; Zeryehun, 2012; Demissie et al., 2013; Lemma and Abera, 2013; Ayana and Ifa, 2015; Mohammed et al., 2015). On the other hand, the analysis of goat faecal samples showed approximately low incidence of trichostrongyle eggs (14.7\%) which is slightly lower than that reported in Menofia governorate $(18.42 \%)$ by El-khtam, (2011). A very lower incidence of $3.7 \%$ was detected at Aswan governorate by Hamad, (2018). Higher incidences were recorded from many African countries as Nigeria (35.4 - 93\% by Nwosu et al., 1996; Nwosu et al., 2007; Gana et al., 2015), Ethiopia $(53.3 \%-100 \%$ by Abede and Esayas, 2001; Zeryehun, 2012; Demissie et al. 2013; Ayana and Ifa, 2015), Zimbabwe (31\% by Zvinorova et al., 2016) and also Somalia $72.1 \%$ by AbdiSoojeede, (2018), while the incidence was $43.8 \%$ in Saudi Arabia by El-Azazy, (1995). The overall incidence of trichostrongyle eggs in sheep was much higher than goats. Similar reports which support this result as Zeryehun, 2012 (67.75 and $55.47 \%$ for sheep and goats, 
respectively), Yagoob and Razi, 2013 (88\% and 79.5\%); Adediran et al., 2014 (96.1\% and $89.3 \%)$ and Gana et al., 2015 (71\% and 62\%). On the opposite, some authors noted similar incidence in both sheep and goats like Ayana and Ifa, 2015 (47.8\% for sheep and $53.3 \%$ for goats); Dilgasa et al., 2015 (68.4\% for sheep and $70.7 \%$ for goats) and Jegede et al., 2015 (34.1\% for sheep and $37.5 \%$ for goats). These incidence variations in both animal species may be attributed to their grazing habits. In addition, the disparity in their immunity levels could play an important role in this difference (Le Riche et al., 1973; Suh et al., 1980; Javed et al., 1992). The incidence according to districts revealed the highest infection rate of trichostrongyle eggs in El Mahella -Elkubra in both sheep (92.5\%) and goats (27.8\%), whereas the lowest incidence was found in the examined sheep and goat in Biyala (10 and $0 \%$, respectively). Other districts showed relatively similar incidences. For instance, the incidence was 34.3\%, 30\% and $21.6 \%$ for sheep samples in Talkha, Dekernes and Nabrouh, respectively. Whereas, the incidence was $13.2 \%, 14.2 \%$ and $16.6 \%$ in goat samples from the same previously districts, respectively. The high incidence rate of trichostrongyles for small ruminants in El Mahella -Elkubra may be due to the management pattern in this district. The most samples were collected from small herds which kept by the Bedouins who are relatively neglectful about their animal`s health. In addition, systematic program of anthelmintic drugs were not applied. Moreover, few number of various animal species like cattle, buffaloes, sheep and goats which are found jointly in these herds that retain the parasite's life cycles and also increase the chance of its transmission among various hosts. Regarding the incidence rate of trichostrongyle eggs in sheep according to age groups in this study, the results revealed that young aged animals less than 1 year $(78.35 \%)$ were extremely affected than old aged ones more than 1 year (15.22\%). Most of the previous studies mentioned similar results. For instance, Tariq et al., 2008 from India $(87.7 \%$ for young sheep and $46.6 \%$ for old sheep); Khan, $2010(27.04 \%$ and $15.67 \%$, respectively); Zeryehun, 2012 (64.52\% and 56.29\%); Lemma and Abera, 2013 (79.6\% and 62.4\%); Daniel et al., 2014 (97.4\% and 79.0\%); Hassanen, 2014 (70.6\% and 51.9\%); Mesele et al., 2014 (28.5\% and 25.9\%) and Mohammed et al., 2015 (85.5\% and 56.5\%). In contrast, Yagoob and Razi, (2013) said that adult sheep and goats aged 3-5 years were more susceptible to the infection than young animals aged 1-2 years as well as Ayana and Ifa, $2015 \quad(75 \%$ and $48.4 \%$, respectively). 
In goats; samples of young animals illustrated a higher incidence of $20.27 \%$. Meanwhile, older animals revealed a lower incidence of $4.87 \%$. These results are agreed with Arafa and Fouad, 2008 (97.4\% and 87.3\%); Khan, 2010 (27.14\% and 20\%) and Zvinorova et al., 2016 (76\% and $38 \%$ ). On the other hand, reverse results were recorded by Ma et al., 2014 and Jegede et al., 2015 (32.1\% for adults and $5.4 \%$ for young goats). The variations in incidence of different ages may be attributed to the immunity factor. Young animals displayed low immunity in compared to adults so that they are more susceptible to the infection of trichostrongyles than adults (Abd El Tawab, 1998; Asif et al., 2008; Abouzeid.et al., 2010).

With regard to animal sex, females of both sheep and goats are found more infected with trichostrongyle eggs (36\% in sheep and $20.27 \%$ in goats) than males $(8.57 \%$ in sheep and $4.87 \%$ in goats). In sheep, these results are agreed with those previously recorded by Khan, 2010 (28.67\% for females and $19.81 \%$ for males); Kuchai et al., 2011 (76.28\% and 63.05\%); Zeryehun, 2012 (62.53\% and 60.41); Adediran et al., 2014 (94.1\% and 87.8\%); Muhammed et al., $2015(66.9 \%$ and $60.8 \%)$ and Jegede et al., 2015 (26.8\% and 10.7\%). However, nearly similiar incidences were detected by Tariq et al., 2008 (70.2\% for males and
68.7\% for females); Ayana and Ifa, 2015 (50\% and $48.5 \%$ for males and females, respectively) and Dilgasa et al., 2015 (71.3\% and 68\%, respectively). Furthermore, earlier investigations on goats support these results; Valcarcel and Romero (2002) and Khan (2010) found much trichostrongyles incidence for females (91 and 30.33\%) than males (86 and $19.72 \%$ ), respectively and Jegede et al., 2015 (26.8\% for females and $10.7 \%$ for males), while Zvinorova et al. (2016) noted opposite results (77\% for males and $55 \%$ for females).

The higher infection rate of trichostrongyles was in females may be attributed to several stress factors considering a challenge for their immunity system as pregnancy and parturition as well as lactation which can decline their immunity levels (Urquhart et al., 1996). Dealing with seasonal incidence of trichostrongyles infection in sheep, it is observed that the rate of infection increased gradually in autumn (33.9\%) to reach at its maximum level in winter $(57.1 \%)$ then, declined slightly in spring season (33.3\%) and completely disappeared during Summer. This result is found coincided with Anene et al., 1994; Kuchai et al., 2011; Zeryehun, 2012 who stated that wet season has higher incidence than dry season. Also, the highest infection of GIT nematodes was recorded in winter by Hassanen, 2014. 
In goats, infection with trichostrongyle eggs is observed only during Winter $(13.3 \%)$ and Summer $(18.7 \%)$. This result is found to agree with Sharma, (2012) who reported that the maximum range of infection was during July. The variation in seasons may be due to the hypobiosis phenomenon of trichostrongyles in antagonistic environmental conditions which gravitate to be higher in intensely cold winter or highly hot summer (Soulsby, 1982) or due to the variable number of samples examined in each season.
CONCLUSION\& RECOMMENDATION

Trichostrongyles eggs were recorded in small ruminants at variable rates with respect to risk factors as age, sex and animal species. Emphasis should be kept in mind for the control of GIT nematodes infection.

From our opinion, further studies about molecular characterization are needed for accurate identification of different trichostrongyle species, rather than the nonreliable and more labor microscopic differentiation. 
Table (1): Incidence of trichostrongyle eggs revealed from sheep and goat faecal samples in study area:

\begin{tabular}{|c|c|c|c|c|c|c|c|c|c|c|c|c|c|c|c|c|c|}
\hline \multirow{2}{*}{ Animal } & \multicolumn{15}{|c|}{ Centers } & \multirow{2}{*}{\multicolumn{2}{|c|}{ Total }} \\
\hline & \multicolumn{3}{|c|}{ Talkha } & \multicolumn{3}{|c|}{ Dekernes } & \multicolumn{3}{|c|}{ Nabrouh } & \multicolumn{3}{|c|}{ EIMahella-Elkubra } & \multicolumn{3}{|c|}{ Biyala } & & \\
\hline \multirow{2}{*}{ Sheep } & No. ex. & $\begin{array}{l}\text { No. } \\
\text { +ve }\end{array}$ & $\%+v e$ & No. ex. & $\begin{array}{l}\text { No. } \\
\text { +ve }\end{array}$ & $\begin{array}{c}\%+ \\
\text { ve }\end{array}$ & No. ex. & $\begin{array}{l}\text { No. } \\
\text { +ve }\end{array}$ & $\begin{array}{c}\%+ \\
\text { ve }\end{array}$ & No. ex. & $\begin{array}{l}\text { No. } \\
\text { +ve }\end{array}$ & $\begin{array}{c}\%+ \\
\text { ve }\end{array}$ & No. ex. & $\begin{array}{l}\text { No. } \\
\text { +ve }\end{array}$ & $\%+v e$ & $\begin{array}{l}\text { No. } \\
\text { +ve }\end{array}$ & $+\mathbf{v e} \%$ \\
\hline & 160 & 55 & 34.3 & 40 & 12 & 30 & 83 & 18 & 21.6 & 27 & 25 & 92.5 & 30 & 3 & 10 & 113 & 33.23 \\
\hline \multirow{2}{*}{ Goats } & No. ex. & $\begin{array}{l}\text { No. } \\
\text { +ve }\end{array}$ & $\%+v e$ & No. ex. & $\begin{array}{l}\text { No. } \\
\text { +ve }\end{array}$ & $\begin{array}{c}\%+ \\
\text { ve }\end{array}$ & No. ex. & $\begin{array}{l}\text { No. } \\
\text { +ve }\end{array}$ & $\begin{array}{c}\%+ \\
\text { ve }\end{array}$ & No. ex. & $\begin{array}{l}\text { No. } \\
\text { +ve }\end{array}$ & $\begin{array}{c}\%+ \\
\text { ve }\end{array}$ & No. ex. & $\begin{array}{l}\text { No. } \\
\text { +ve }\end{array}$ & $+v e \%$ & $\begin{array}{l}\text { No. } \\
\text { +ve }\end{array}$ & $+v e \%$ \\
\hline & 68 & 9 & 13.2 & 7 & 1 & 14.2 & 12 & 2 & 16.6 & 18 & 5 & 27.8 & 10 & 0 & 0 & 17 & 14.78 \\
\hline
\end{tabular}

Table (2): Incidence of trichostrongyle eggs in sheep and goat faecal samples in relation to ages:

\begin{tabular}{|l|c|c|c|c|c|c|c|c|}
\hline \multirow{2}{*}{ Animals } & \multicolumn{2}{|c|}{ Less than one year } & \multicolumn{2}{c|}{ More than one year } & \multicolumn{2}{c|}{ Total } \\
\hline \multirow{3}{*}{ Sheep } & No. & No. & $\%$ & No. & No. & $\%$ & No. & $\%$ \\
& ex. & + ve & $+v e$ & ex. & + ve & + ve & + ve & $+v e$ \\
\cline { 2 - 9 } & 97 & 76 & 78.35 & 243 & 37 & 15.22 & 113 & 33.23 \\
\hline Goats & 74 & 15 & 20.27 & 41 & 2 & 4.87 & 17 & 14.78 \\
\hline
\end{tabular}


Table (3): Incidence of trichostrongyle eggs in sheep and goat faecal samples regarding to animal sex:

\begin{tabular}{|l|c|c|c|c|c|c|c|c|}
\hline Animals & \multicolumn{3}{|c|}{ Females } & \multicolumn{3}{c|}{ Males } & \multicolumn{2}{c|}{ Total } \\
\hline & No. & No. & $\%$ & No. & No. & $\%$ & No. & $\%$ \\
& ex. & + ve & + ve & ex. & + ve & + ve & + ve & + ve \\
\cline { 2 - 9 } & 305 & 110 & 36 & 35 & 3 & 8.57 & 113 & 33.23 \\
\hline Sheep & 100 & 14 & 20.27 & 15 & 3 & 4.87 & 17 & 14.78 \\
\hline
\end{tabular}

Table (4): Seasonal incidence of trichostrongyle eggs in sheep and goat faecal samples:

\begin{tabular}{|c|c|c|c|c|c|c|c|c|c|c|c|c|c|c|}
\hline Animals & \multicolumn{12}{|c|}{ Seasons } & \multicolumn{2}{|c|}{ Total } \\
\hline & \multicolumn{3}{|c|}{ Autumn } & \multicolumn{3}{|c|}{ Winter } & \multicolumn{3}{|c|}{ Spring } & \multicolumn{3}{|c|}{ Summer } & \multirow{3}{*}{$\begin{array}{l}\text { No. } \\
\text { +ve }\end{array}$} & \multirow{3}{*}{$\begin{array}{r}\% \\
+ \text { ve }\end{array}$} \\
\hline & \multirow{2}{*}{$\begin{array}{l}\text { No. } \\
\text { ex. }\end{array}$} & \multicolumn{2}{|c|}{$+v e$} & \multirow{2}{*}{$\begin{array}{l}\text { No. } \\
\text { ex. }\end{array}$} & \multicolumn{2}{|c|}{ ve+ } & \multirow{2}{*}{$\begin{array}{l}\text { No. } \\
\text { Ex }\end{array}$} & \multicolumn{2}{|c|}{ ve+ } & \multirow{2}{*}{$\begin{array}{c}\text { No. } \\
\text { ex }\end{array}$} & \multicolumn{2}{|c|}{$+v e$} & & \\
\hline & & No. & $\%$ & & No. & $\%$ & & No. & $\%$ & & No & $\%$ & & \\
\hline Sheep & 56 & 19 & 33.9 & 147 & 84 & 57.1 & 30 & 10 & 33.3 & 107 & 0 & 0 & 113 & 33.23 \\
\hline Goats & 10 & 0 & 0 & 15 & 2 & 13.3 & 10 & 0 & 0 & 80 & 15 & 18.7 & 17 & 14.78 \\
\hline
\end{tabular}


Figure (1): Trichostrongyle egg

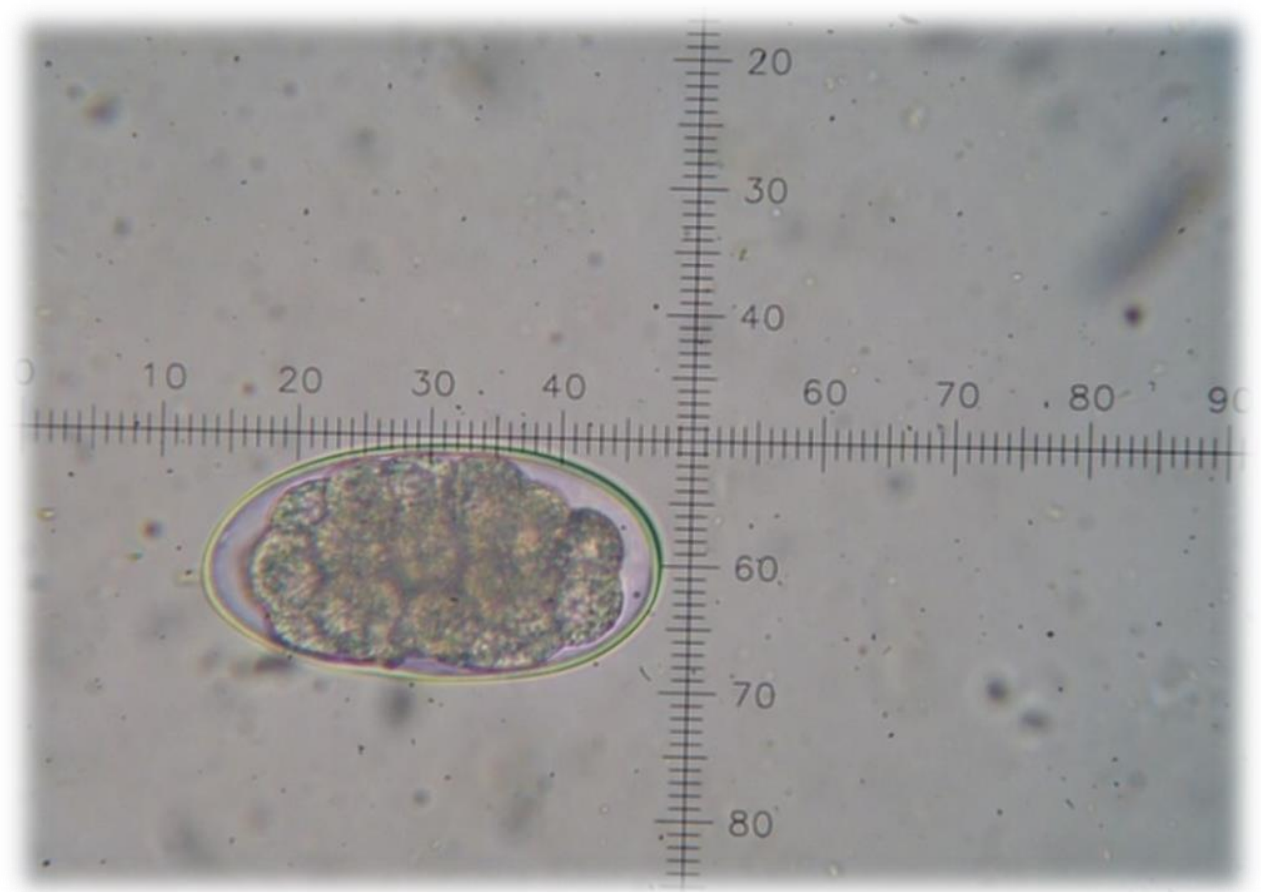




\section{Elsedawy et al}

\section{REFERENCES}

Abd El-Tawab, F.A.M.G. (1998): Some studies

on the intestinal helminths of sheep with

references to Trichuris ovis. Ph.D.Veterinary

Sciences Faculty of Veterinary Medicine, Cairo

University.

Abdi-Soojeede, M. I. (2018): Common gastrointestinal parasites of goats (Capra aegagrus hircus) from Mogadishu, Somalia. Open Journal of Veterinary Medicine; 8: 232-240.

Abede, W. and Esayas, G. (2001): Survey of ovine and caprine gastro-intestinal helminthasis in eastern part of Ethiopia during the dry season of the year. Revue de Medicine Veterinaire; 152 (5): 379-384.

Abouzeid, N. Z.; Selim, A. M. and El- Hady, K. M. (2010): Prevalence of gastrointestinal parasites infections in sheep in the Zoo garden and Sinai district and study the efficacy of anthelmntic drugs in the treatment of these parasites. Journal of Americian Science; 6 (11): 544-551.

Adediran, O. A.; Adebiyi, A. I. and Uwalaka, E. C. (2014): Distribution of gastrointestinal helminthosis of small ruminants in Ibadan, South Western Nigeria: Role of Traditional Rearing System. Nature and Science; 12 (9): 25-29.

Al-Aboody, M.S. and Omar, M.A. (2016):

Prevalence of gastrointestinal nematodes of farm animals by coproculture. Russian Journal of Parasitology; 36 (2): 168-174.

Anene, B. M.; Onyekwodiri, E. O.; Chime, A. B. and Anika, S. M. (1994): Gastrointestinal parasites in sheep and goats of southern Nigeria. Small Ruminant Research; 13 (2): 187- 192.

Arafa, M. I. and Fouad, I. A. (2008): Studies on some internal parasites of goats in Assiut Governorate especially which affecting
EVMPSJ 2018,14:121-136

liver. Assiut University Bulletin Environmental Research; 11: 57-73.

Asif, M.; Azeem, S.; Asif, S. and Nazir, S. (2008): Prevalence of gastrointestinal parasites of sheep and goats in and around Rawalpindi and Islamabad, Pakistan. Journal of Veterinary and Animal Sciences; 1: 14-17.

Assasa, A. Z. A. (2018):

Morphobiological studies on gastrointestinal nematodes in ruminants. Thesis (M. S.); Suez Canal University. Faculty of Veterinary Medicine.

Ayana, T. and Ifa, W. (2015): Major gastrointestinal helminth parasites of grazing small ruminants in and around Ambo town of Central Oromia, Ethiopia. Journal of Veterinary Medicine and Animal Health; 7 (2): 64-70.

Chaudhary, F.R.; Khan, M.F.U. and

Qayyum, M. (2007): Prevalence of Haemonchus contortus in naturally infected small ruminants grazing in the Photohar area of Pakistan. Pakistan Veterinary Journal; 27: 73-79.

Coop, R. L.; Sykes, A. R. and Angus, K. W. (1977): The effect of a daily intake of Ostertagia circumcincta larvae on body weight, food intake and concentration of serum constituents in sheep. Research in veterinary science; 23 (1): 76.

Cox, D. D. and Todd, A. C. (1962): Survey of gastrointestinal parasitism in Wisconsin dairy cattle. Journal of the American Veterinary Medicine Association; 141: 706-709. 


\section{Elsedawy et al}

Daniel, A.; Deneke, Y. and Ibrahim, N. (2014):

Gastrointestinal parasites in sheep in Gemechis and Boke District, West Harerghe Zone, Ethiopia. Acta Parasitology Globalis; 5 (2): 120-124.

Demissie, T.; Tesfaye, D.; Fekadu, A. and

Asefa, I. (2013): Study on abomasal nematodes of sheep and goats: comparison and characterization of vulvar morphology of Haemonchus in Hawassa, Ethiopia. African Journal Agriculture Research; 8 (41): 5181-5186.

DOI10.5897/AJAR2013.7350.

Dilgasa, L.; Asrade, B. and Kasaye, S. (2015):

Prevalence of gastrointestinal nematodes of small ruminants in and around Arsi Negele town, Ethiopia. American Eurasian Journal of Scientific Research; 10 (3): 121-125.

El-Alfy, E. N. E. (2017): Studies on parasites infecting farm animals in Dakahlia Province. Thesis (M. S.); Mansoura University. Faculty of Veterinary Medicine.

El-Azazy, O. M. E. (1995): Seasonal changes and inhibited development of the abomasal nematodes of sheep and goats in Saudi Arabia. Veterinary Parasitology; 58 (1-2): 91-98.

El-Khtam, A. O. A. (2011): Studies on diagnosis and control of nematodes. Thesis (M. S.); Menofia University. Faculty of Veterinary Medicine.

Fakae, B. B. (1990): The epidemiology of helminthosis in the small ruminants under the traditional husbandry system in eastern Nigeria. Veterinary Research Communication; 14 (5): 38191.

Gadahi, J.A.; Arshed, M.J.; Ali, Q.; Javaid, S.B. and Shah, S.I. (2009): Prevalence of gastrointestinal parasites of sheep and goats in and around Rawalpindi and Islamabad. Pakistan Veterinary World; 2: 51-53.
EVMPSJ 2018,14:121-136

Gana, J. J.; Makun, H.; Chiezey, N. P. and Tekdek, L. B. (2015):

Epidemiological study on abomasal nematodes in slaughtered small ruminants raised in the guinea savannah zone of Nigeria. Sokoto Journal of Veterinary Sciences; 13 (2): 26-33.

Garcia, R.C.; Valcarcel, S.F.; del Cordero C.M. and Rojo, V.F.A. (1993): Aetiology and epizootiology of trichostrongyle infections in sheep in the Oropesa region (Toledo). Invest Agraria, Production Sanid Animal; 8: 155-168.

Hamad, S. M. H. (2018): Helminthiasis of small ruminants in Nubian Villages, Aswan. Thesis (M. S.); Assiut University. Faculty of Veterinary Medicine.

Hassanen, E. A. A. (2014):

Parasitological and molecular biology studies on gastric nematodes in small ruminants at Sharkia province, Egypt. Ph.D. Thesis, Faculty of Veterinary Medicine, Zagazig University. Javed, M.S.; Iqbal, Z. and Hayat, B. (1992): Prevalence and economics of haemonchosis in sheep and goats. Pakistan. Veterinary Journal; 12 (1): 3638.

Jegede, O. C.; Adejoh, A. A.; Obeta, S. S. and Olayemi, O. D. (2015):

Gastrointestinal parasites of sheep and goats in Gwagwalada Area Council, federal capital territory, Abuja, Nigeria; with special reference to sex, breed and age. Alexandria Journal for Veterinary Sciences; 46 (1): 170-176.

Khalafalla, R. E.; Elseify, M. A. and Elbahy, N. M. (2011): Seasonal 
prevalence of gastrointestinal nematode parasites of sheep in Northern region of Nile Delta, Egypt. Parasitology Research; 108 (2): 337-340.

Khan, M. N.; Sajid, M. S.; Khan, M.

K.; Iqbal, Z. and Hussain, A. (2010):

Gastrointestinal helminthiasis: prevalence and associated determinants in domestic ruminants of district Tobatek Singh, Punjab, Pakistan. Parasitology Research; 107 (4): 787-794.

Kuchai, J. A.; Chishti, M. Z.; Zaki, M. M.; Javid, A.; Dar, S. A.; Muzaffar, R. and Tak, H. (2011): Epidemiology of helminth parasites in small ruminants of Ladakh, India. Online Journal Animal Feed Research; 1 (5): 239-242.

Lemma, D. and Abera, B. (2013): Prevalence of ovine gastrointestinal nematodes in and around Asella, South Eastern Ethiopia. Journal of Veterinary Medicine and Animal Health; 5 (8): 222228.

Le Riche, P.D.; Efastathiou, G.C.; Campbell, J.B. and Altan, Y. (1973): A helminth survey of sheep and goats in Cyprus: I- The seasonal distribution and prevalence of gastrointestinal parasites. Journal Helminthology; 47 (3):237-250. Ma, J.; He, S. W.; Li, H.; Guo, Q. C.; Pan, W. W.; Wang, X. J.; Zhang, J.; Liu, L. Z.; Liu, W. and Liu, Y. (2014): First survey of helminths in adult goats in Hunan province, China. Tropical Biomedicine; 31 (2): 261-269.

Menshawy, S. M. G. (2011): Studies on gastrointestinal nematodes infestation in sheep in Beheira Governorate. Thesis (M.
S.); Damanhour University. Faculty of Veterinary Medicine.

Mesele, K.; Yisehak, T. R. and Nesibu, A. (2014): Prevalence of Haemonchosis in sheep slaughtered at Abergele Export Abattoir. Acta Parasitological Globalis; 5 (2): 115-119.

Mohammed, A.; Disassa, H.; Kabeta, T.;

Zenebe, T. and Kebede, G. (2015): Prevalence of gastrointestinal nematodes of sheep in Gursum Woreda of eastern Hararghe Zone, Oromia. regional state, Ethiopia Researcher; 7 (8): 45-54. Nabavi, R.; Eslami, A.; Shokrani, H. R.; Bokaie, S.; Shayan, P. and Saadati, D. (2011): Study on the prevalence, intensity and seasonal dynamics of abomasal helminths in sheep from different climatic zones of Iran. World Applied Sciences Journal; 12 (4): 441-445.

Nawathe, D. R.; Sohael, A. S. and Umo, L. (1985): Health towards secondary infection the sexwise prevalence management of dairy herd on the jos plateau of helminth parasites of GIT shows higher prevalence (Nigeria). Buletin Animal Health Production Africa; 33: 199-205.

Nwosu, C. O.; Ogunrinade, A. F. and Faqbemi, B. O. (1996): Prevalence and seasonal changes in the gastro-intestinal helminths of Nigerian goats. Journal of Helminthology; 70 (4): 329-33.

Nwosu, C. O.; Madu, P. P. and Richards, W. S. (2007): Prevalence and seasonal changes in the population of gastrointestinal nematodes of small ruminants in the semi-arid zone of north-eastern Nigeria. Veterinary Parasitology; 144 (1): 118124.

Odoi, A.; Gathuma, J.M.; Gachuiri, C.K. and Omore, A. (2007): Risk factors of gastrointestinal nematode parasite infections in small ruminants kept in smallholder mixed farms in Kenya. BMC Veterinary Research; 3: 1186-1746. 
Pawel, G.; Niznikowski, R.; Strzelec,

E.; Popie-Larczyk, D.; Gajewska, A. and Wedrychowtcz, H. (2004):

Prevalence of protozoan and helminth internal parasite infections in goat and sheep flocks in Poland. Archiv fur Tierzucht; 47: 43-49.

Pedreira, J.; Silva, A.P.; Andrade, R.S.;

Suarez, J.L.; Arias, M.; Lomba, C.; Diaz, P.; Lopez, C.; Banos, P.D. and Morrondo, P. (2006): Prevalence of gastrointestinal parasites in sheep and parasite control practices in North-West Spain. Preventive Veterinary Medicine; 75: 56-62.

\section{Rehbein, S.; Kollmannsberger, M.;}

Visser, M. and Winter, R. (1996): The helminth fauna of slaughtered sheep from upper Bavaria 1: Species composition, prevalence and worm counts. Berliner und Münchener Tierarztliche Wschenschrift; 109: 161-167.

Sharma, S. (2012): Studies on prevalence, clinic-biochemical and histopathological aspects of helminth parasites of goats in Anand district. Doctoral dissertation, Anand Agricultural University, Anand.

Soulsby, E. J. L. (1982): Helminths, arthropods and the protozoa of domesticated animals $7^{\text {th }}$ edition. Bailience Tindall and Cassell.

Steel, J.W.; Jones, W. O. and Symons, L. E. A. (1982): Effects of concurrent infection of Trichostrongylus colubriformis on the productivity and physiological and metabolic responses of lambs infected with Ostertagia circumcincata. Australian Journal of Agriculture Research; 33 (1): 131-140. Suh, M. D.; Kim, C. S. and Jung, M. K. (1980): Epidemiological study on the infection rate of internal parasites of sheep at an Alpine breeding station. Research Reports Rural Development Korea; 22: 138-146.

Sultan, K.; Elmonir, W. and Hegazy, Y. (2016): Gastrointestinal parasites of sheep in Kafrelsheikh governorate, Egypt: Prevalence, control and public health implications. Beni-Suef University Journal of Basic and Applied Sciences; 5 (1): 7984.

Tariq, K. A.; Chishti, M. Z.; Ahmad, F. and Shawl, A. S. (2008): Epidemiology of gastrointestinal nematodes of sheep managed under traditional husbandary system in Kashmir valley. Veterinary Parasitology; 158 (1-2): 138143.

Thomas, N.; Teshale, S. and Kumsa, B. (2007): Abomasal nematodes of sheep and goats slaughtered in Awassa (Ethiopia): species composition, prevalence and vulvar morphology. Helminthologia; 44 (2): 70-75.

Urquhart, G. M.; Armour, J.; Duncan, J. L.; Dunn, A. M. and Jennings, F. W. (1996):

Veterinary Parasitology. Second edition, Blackwell Science, Pp 356.

Valcarcel, F. and Romero, G. (2002):

Prevalence and seasonal pattern of caprine Trichostrongyles in a dry area of Central Spain. Journal of Veterinary Medicine, series B banner; 46 (10): 673-681.

Veale, P.I. (2002): Resistance to macrocyclic lactones in nematodes of goats. Australian Veterinary Journal; 80: 303-304. 
Elsedawy et al

Waller, P. J. (1997): Anthelmintic

resistance. Veterinary Parasitology; 72:

391-412.

Yagoob, G. and Razi, B. S. (2013):

Seasonal prevalence of abomasal

nematodes in small ruminants slaughtered

at Tabriz town, Iran. Life Science Journal;

10 (5s): 206-209.

Zarlenga, D. S.; Hoberg, E. P. and Tuo,

W. (2016): The identification of

Haemonchus species and diagnosis of

haemonchosis. In Advances in

parasitology; 93: 145-180. Academic

Press.

\section{EVMPSJ 2018,14:121-136}

Zeryehun, T. W. (2012): Helminthosis of sheep and goats in and around Haramaya, south eastern Ethiopia. Journal of Veterinary Medicine and Animal Health; 4 (3): 48-55.

Zvinorova, P. I.; Halimani, T. E.;

Muchadeyi, F. C.; Matika, O.; Riggio, V. and Dzama, K. (2016): Prevalence and risk factors of gastrointestinal parasitic infections in goats in low input and low-out put farming systems in Zimbabwe. Small Ruminant Research; 143: 75-83. 


\section{الملخص العربي}

مدي انتشار بويضات التريكوسترونجيل في الاغنام والماعزفي محافظه الدقهليه ومحيطها مع

\section{اعتبار عو امل الخطر المحتملة}

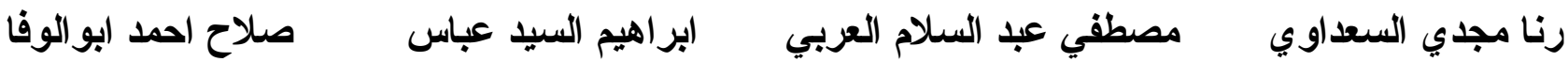

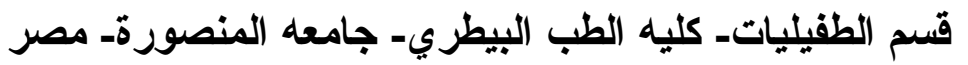

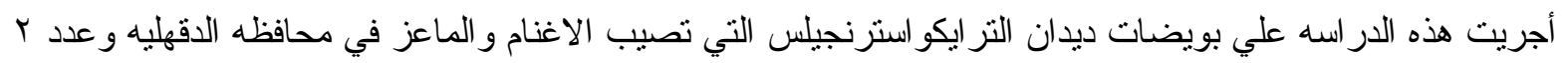
من المر اكز الحدوديه لها (المحله الكبري التابعه لمحافظه الغربيه- بيلا التابعه لمحافظه كفر الثيخ) , لتحديد نسب الاصديابه و در اسه العو امل الخطر المحتمله التي تزيد من حدوث الاصابه بهذه الديدان في الاغنام و الماعز. وقد تم فحص عدد 00؛عينه بر از من الاغنام والماعزمن المدن الاتيه : طلخا ونبروه ودكرنس والمحله الكبري وبيله في الفترة ما بين أكتوبر r. V

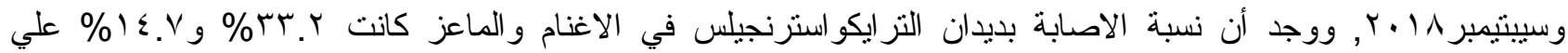
التزتيب.

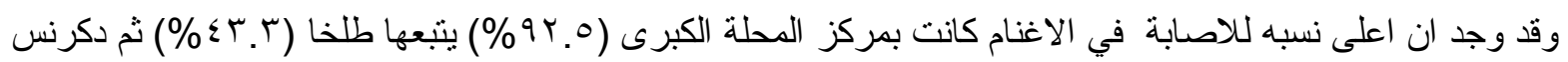

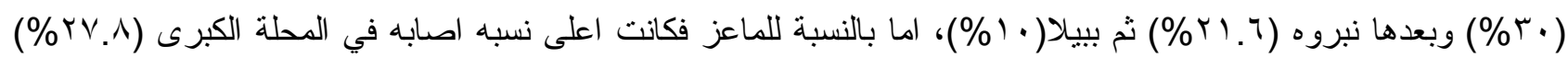

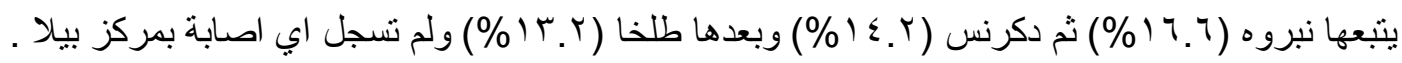
و بالنسبة لمدي انتشارنلك الديدان علي حسب الاعمار المختلفة، فقد لوحظ ان نسبه الاصابة في الاعمار الاصغر من

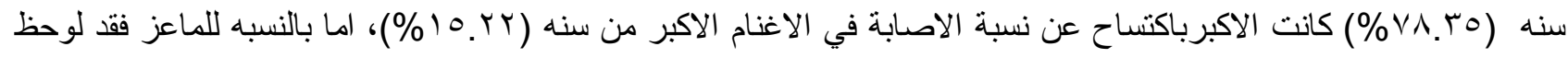

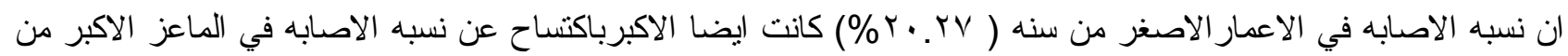

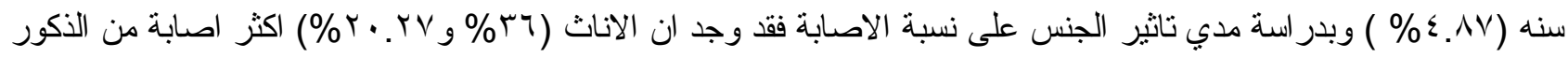

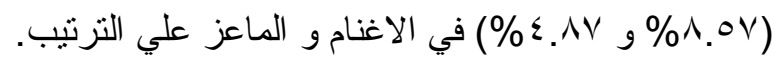
وبدر اسه تباين الاصابه الموسمبه في الاغنام فقد وجد ان نسبه الاصدابه بدات في الزياده في فصل الخريف (9.بr\%)

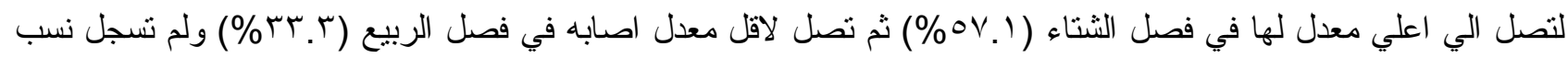

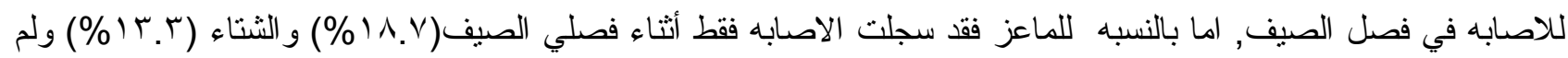
نسجل نسب للاصابه في فصلي الخريف و الربيع. وقد خلصت هذه الدراسه الي التوصيه باستخدام البيولوجيا الجزيئيه في تصنيف الانواع المختلفه من ديدان الترايكو استرنجيلس لضمان التشخيص الدقيق فضلا عن استخدام الطرق الروتنيه لفحص البراز باستخدام الميكروسكوب في فحص البويضات و اليرقات نظر اللفروق البسيطه بين الانو اع المختلفه. 